\title{
The hunting of the Greenland right whale in Svalbard, its interaction with climate and its impact on the marine ecosystem
}

\author{
Louwrens Hacquebord
}

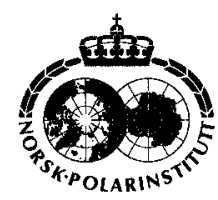

\begin{abstract}
During the 17th and 18th centuries, tens of thousands of Greenland right whales were killed as a result of extensive European whaling in the coastal waters of the Svalbard archipelago. The author reconstructed these whaling activities, examined how the changing climate affected whaling productivity, and considered the consequences of climate and whaling on the species and on the North Atlantic ecosystem. Annual catch records made it possible to calculate the original size of the whale population; its natural migration pattern in the Greenland Sea could be reconstructed using shipping logs and itineraries. Other written sources revealed that besides human hunting activities, climate change played an important role in the elimination of the Greenland right whale from the Arctic marine ecosystem. This elimination made millions of plankton available for other marine mammals, polar cod and planktonfeeding birds. This has caused a major shift in the food web. changing the marine ecosystem in Svalbard.
\end{abstract}

L. Hacquebord, Arctic Centre, University of Groningen, Oude Kijk in 't Jatstraat 26, 9712 EK Groningen, The Netherlands.

\section{Introduction}

Apart from recent ice core and tree ring studies (Overpeck et al. 1997), research on global change often has a shallow historical dimension, dealing with data from a period of a few decades only. Similarly, impact studies seldom take into account that recently impacted ecosystems might have undergone earlier transformations due to human activities. The whaling history of Svalbard provides an excellent opportunity to study such changes and their consequences for the present ecosystem.

Four centuries ago England and The Netherlands started whaling in the waters around Spitsbergen, the main island of the Svalbard archipelago (Jackson 1978; Hacquebord 1984a; Bruijn 1988). This whaling trade lasted almost three hundred years and its success was very dependent on ice and weather conditions (Hacquebord 1984b). In the end, whaling in Svalbard led to a complete removal of the Greenland right whale (Balaena mysticetus), or bowhead, from the marine ecosystem (Hacquebord \& Leinenga 1994).
During twenty years of archaeological field research on Spitsbergen a great deal of evidence of whaling activities has been found. At almost every suitable place along the beaches of the west coast, the 17th century European whalers had built whaling stations where blubber of the whales killed was rendered into oil (Hacquebord 1984a; 1988a). Many bones and sometimes even complete skeletons of Greenland right whales have been found at these sites. The remains indicate the former existence of a large whale population. Recently, it is only around the islands of Frans Jozef Land that there have been sightings of Greenland whales (Moore \& Reeves 1993; de Korte \& Belikov 1994). Although right whales have been protected since 1937, sightings of Greenland right whales in the waters of Svalbard have been very rare.

This article will focus on the following questions: What caused the extermination of the Greenland right whale in the Atlantic Arctic? What consequences did the resulting availability of large quantities of zooplankton have for the ecosystem? 


\section{Sources and methods}

This study was set up as a multidisciplinary research project to find answers to the questions posed above. From 1979 to 1998 data were derived from archaeological, historical and biological sources.

Archaeological excavations were carried out on several locations on the west coast of Spitsbergen: Amsterdamøya and Ytre Norskøya (1979-1981, 1983, 1986 and 1987) on the northern parts of this coast and Laegerneset (1998) in the south. Archaeological structures and material culture were studied to improve knowledge of whaling in Svalbard. The remains of fauna excavated in the middens were studied for what they could reveal about the natural environment. Pollen analysis of soil samples around the settlement gave information on vegetation changes around the settlements (van der Knaap 1985).

Written sources were used to reconstruct the whaling history and to collect more information on the ecology of the Greenland right whale, its early habitat and its former migration route. The historical information was compared with the results of recent biological research in the Bering, Chukchi and Beaufort seas on the only remaining substantial Greenland right whale population (Everitt \& Krogman 1979; Leatherwood \& Reeves 1983: Hazard \& Lowry 1984; Nerini et al. 1984; Burns et al. 1993). In this way, it was possible to study the life history of the Greenland right whale in the Greenland Sea although the species has become very rare.

The catch records informed us about the number of whales killed per voyage and per ship from 1669 to 1800 . Several lists have been preserved; the figures on the different lists corresponded with each other rather well. These lists were used to calculate the number of Greenland right whales before exploitation and to assess the impact of whaling on this population. Besides logbooks and catch records, other written sources also provided information about whaling. Very often the place, the moment and the circumstances under which a whale was killed were noted in official notarial documents. These documents were used to reconstruct the distribution of the whales in the hunting area. Preserved trade correspondence and newspapers provided additional information about the economic aspects of whaling. Whale bones on the beaches were used to study the distribution of the whales around the Arctic islands and this informa- tion was compared with the sightings of whales noted down in the historical sources. The bird bones from the middens were used to reconstruct the avifauna around the whaling stations and this reconstruction was compared with recent bird cliffs. Finally, samples were taken of the guano layers under the bird cliffs to date the rookeries and to get information about the birds who formed these layers. Moreover, pollen analyses of the guano samples yielded clues regarding the climate during the sedimentation of the guano layers (van der Knaap 1985).

\section{The Greenland right whale}

One of the first biological descriptions of the Greenland right whale is given in the book Drie Voyagien gedaen na Groenlandt . . . which was published around 1668 by Gillis Joosten Saeghman in Amsterdam. This book reveals that 17th century whalers knew a great deal about the biology of whales, probably because they were excellent observers. According to early descriptions and new biological research in Alaska the Greenland right whale is a large whale which belongs to the family of the baleen whales (Balaenidae). The whale's name comes from the baleen plates in its mouth. With these sometimes more than $4 \mathrm{~m}$ long baleen plates the whale can sift the zooplankton out of the sea water (Leatherwood \& Reeves 1983).

The length of the Greenland right whale varies between 12 and $18 \mathrm{~m}$ (Haldiman \& Tarpley 1993). The average weight of an adult whale is about 75 to 100 tonnes. The body colouration is black and the whale has a white spot on its chin and a lighter spot on the tail stock and/or fluke plates. The head is about one third of the total body length and the bonnet callosities characteristic of this family are absent on the upper part of the head. The Greenland right whale has a higher arch of the upper jaw than related species, such as the northern and southern right whales. The widely separated blowholes cause a double blow, the Vshape of which is characteristic of the Greenland right whale. The eyes are placed quite low on the side of the head, about $30 \mathrm{~cm}$ above the corner of the mouth (Haldiman \& Tarpley 1993).

Greenland right whales are endemic to Arctic and sub-Arctic waters. They are usually not seen south of $68^{\circ} \mathrm{N}$. In the (sub-)Arctic, the whales 


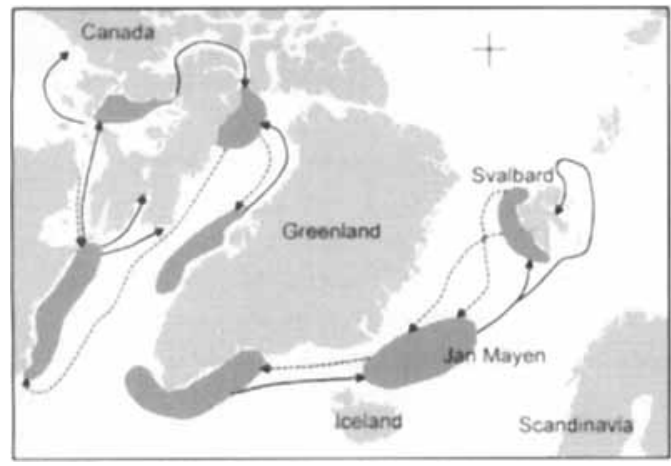

Fig. 1. Reconstruction of the migration routes of Greenland right whales in the 17 th and 18 th centuries. Illustration by $F$. Steenhuisen and Huib Waterbolk.

spend a great part of their life close to the edge of the pack ice in the waters near arctic and subarctic islands. From historical sources, it appears that the $200 \mathrm{~m}$ depth contour is of great significance to them (Hacquebord 1984a).

\section{The migration of the Greenland right whale}

Historical sources, in combination with results of recent biological research in the Bering, Chukchi, Beaufort seas and Baffin Bay, have made it possible to reconstruct the life history and migration of Greenland right whales in the Atlantic Arctic (Burns et al. 1993; Hacquebord \& Leinenga 1994). The Greenland right whales wintered along the edge of the pack ice east and south-east of Greenland and migrated to the north in the springtime, following the retreating edge (Fig. 1). In 1634, the Dutch sailors who wintered on Jan Mayen observed the first whales on 28 March (l' Honoré Naber 1930).

Greenland right whales fed primarily on small to medium-sized zooplankton, animals (euphausiids, copepods, mysids, pteropods and amphipods) found in concentrations along the ice edge near islands in the Greenland Sea, at places where there are many nutrients. This availability of nutrients and the thickness of the ice determines both the growth of phyto- and zooplankton. This growth shows a seasonal rhythm with the peak coming later with increasing latitude. The Greenland right whale migrated to the north to feed on this zooplankton and returned south in autumn after the feeding season (Moore \& Reeves 1993).

The whale probably had its calving area near Jan Mayen because pregnant females were caught and many females and young whales were seen near Jan Mayen in the first half of the 17th century. Male and non-pregnant female whales migrated directly to the feeding and mating grounds northwest and north of Spitsbergen. Under certain ice conditions, for instance, when the pack ice was closed and at the edge near the coast of Spitsbergen, many whales concentrated there, making this a productive hunting area. Sometimes it was so crowded with whales in the north-west of Spitsbergen that the whalers called it Whalebay.

The logbook of seven people who overwintered on Amsterdamøya (1633-34) mentioned the first whale sighting on April 27 (l' Honoré Naber 1930). Other written sources name the end of May or the beginning of June as the moment the whales arrived in the fiords of Spitsbergen (Hacquebord \& Leinenga 1994). Later in the season, female and young whales were seen feeding in these fiords (Conway 1900). In this period, whales were also seen in the eastern part of Svalbard and even in the Barents Sea. The remains of whaling stations on some islands south of Edgeøya demonstrate the presence of whales in these waters in former times (Hacquebord 1988b).

\section{Climate change and whaling}

The location of whale feeding and mating grounds was determined by the pack ice, sea currents and climate. Isotope research of ice cores from the Svalbard, Greenlandic and Canadian ice sheets shows cold and warm periods between 1450 and

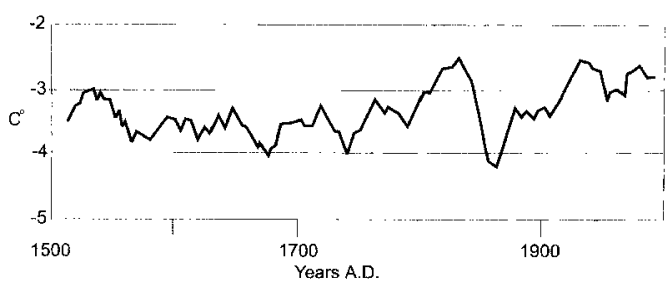

Fig. 2. Mean summer temperature at Austfonna (Nordaustlandet. Svalbard) calculated by the melting model, smoothed by an 11 year filter (data from Tarussov 1992). 
1920 (Dansgaard et al. 1970; Fisher \& Koerner 1980; Tarussov 1992; Overpeck et al. 1997). Temperature profiles of the Svalbard ice cores show a Little Ice Age from 1550 to 1920, with the mean summer temperature being at least $1{ }^{\circ} \mathrm{C}$ lower than the mean summer temperature of the reference period (1901-1960) (Fig. 2). Vinje (1998) has shown a significant correlation between the mean August ice edge in the Greenland and Barents seas and the mean summer temperature in the Northern Hemisphere, making the ice core temperature profiles very relevant for our research.

From the ice cores of Svalbard we know that the second half of the 16th century and the beginning of the 17th century was a cold period, with the mean summer temperature being approximately $1.5^{\circ} \mathrm{C}$ lower than the mean temperature of the reference period (Tarussov 1992). This period was characterized by much sea ice. Whaling took place in the bays of Jan Mayen and Spitsbergen and was controlled by chartered companies from England and The Netherlands which together fitted out approximately thirty ships every year (Hacquebord 1984a).

The Svalbard ice cores show that this cold period was followed by a short warmer period (1625-1645) with mean summer temperatures approximately $0.5^{\circ} \mathrm{C}$ higher than the period before (Tarussov 1992; Overpeck et al. 1997). This warmer period is confirmed by the pollen diagrams of the samples from the guano layers of the bird cliffs on Amsterdamøya (van der Knaap 1985). Vinje (I998) assumes that there were more years with open water in this period. The number of "south ice years" decreased, as did incidents of ice damage to ships (Hacquebord 1984a), and whaling moved into the open sea, west and north of Spitsbergen. The Greenland right whales spread out across the Greenland Sea and were difficult to kill. In the circumstances, Dutch and English charter companies lost their total control of the trade, experiencing much competition from socalled "interlopers," nationals who were not members of the companies. Both companies eventually lost their charters.

After 1645, weather conditions changed again. The ice cores indicate that the mean summer temperature dropped once more (Tarussov 1992; Overpeck et al. 1997). The coldest period in the 17 th century started with many "south ice years" and, according to Vinje (1998), there were many years with ice at $76^{\circ} \mathrm{N}$. The edge of the pack ice was closed more frequently and the whales could not escape into it. Recent observations in the Beaufort Sea show that in such cases the animals concentrate along the edge waiting for the moment the ice opens (Everitt \& Krogman 1979). In the 17 th century, they must have concentrated along
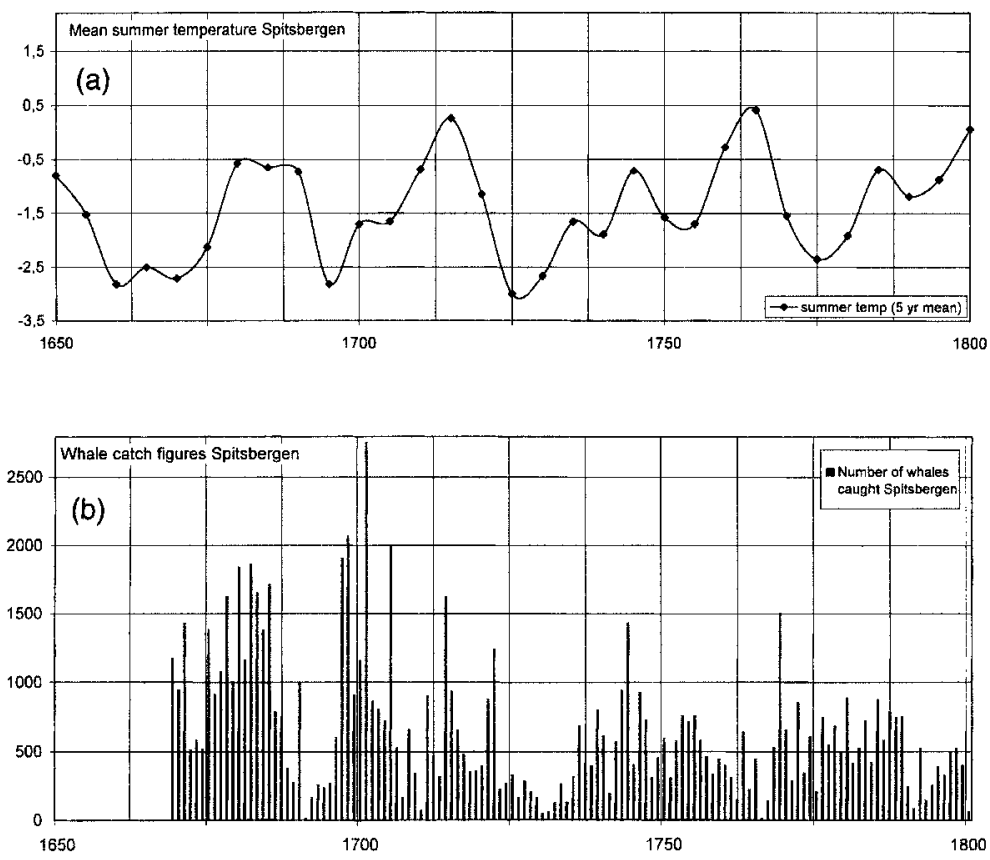

Fig. 3. Comparison of (a) the mean summer temperature at Svalbard with (b) the annual catch of whales in the coastal waters of the Arctic archipelago. 
the edge north of Spitsbergen in the Whalebay. This situation lasted until 1680 (Overpeck et al. 1997).

With whaling having become free to everyone in this period, the yearly number of ships setting out to the north increased, reaching an annual average of 300 . With the pack ice closed in this period many whales were killed, in some years more than 2000 . Whaling became very profitable. This situation, however, was disastrous for the whale population. High levels of stress caused by a combination of whaling and the climate in this coldest period of the 17th century caused a rapid decimation of Greenland right whales (Fig. 3).

When around 1715 the ice opened again, the remaining whales escaped into the pack ice and the success of the whaling at Spitsbergen decreased dramatically. In 1719 the whalers more or less had to open a new hunting area near Disco Island in Davis Strait. However, neither the old nor the new area turned out to be very successful in the following years. This situation altered in the middle of the 18th century, when due to a new change in the climate the number of years with closed pack ice rose. The remaining whales again concentrated along the ice edge more frequently and in both areas whaling experienced some productive years. However, the number of whales decreased to such an extent that one decade later catches declined again and whaling lost its profitability. In the long run, the combination of many "south ice years" and hunting became deadly for the Greenland right whale in the North Atlantic. In the 19th century, the Spitsbergen population was exterminated and halfway through the century whaling finally stopped in this area (Scoresby 1820; Hacquebord \& Leinenga 1994).

\section{Impact of whaling}

Many have tried to estimate stock sizes prior to commercial whaling (Mitchell 1977; IWC 1978; Mitchell \& Reeves 1981; Leatherwood \& Reeves 1983; Hacquebord 1984a; Woodby \& Botkin 1993; Hacquebord \& Leinenga 1994). These estimates and many recently discovered catch records have made it possible to estimate the total stock size at Spitsbergen. The only difficulty is the fact that the preserved records from the first period (1610-1669) of the Spitsbergen whaling trade are not continuous. Only from some years has information been preserved. Building on this admittedly incomplete information, the total catch can be estimated at 15000 whales in this first period. We are much better informed about the catch in the next period. From 1669 onwards the whalers kept catch records on a yearly basis. From 1669 to 1800,86644 whales were killed by English, Dutch and German whalers in the seas between Jan Mayen and Spitsbergen. Taking into account that $20 \%$ of the whales hit were lost (Kugler 1984), we arrive at a total of 122000 whales killed. Assuming a yearly reproduction of $2 \%$, the pre-exploitation population of the Greenland right whale must have been about 46000 (Hacquebord \& Leinenga 1994).

Almost no Greenland right whales remain in the North Atlantic nowadays. This means that 46000 whales have disappeared from the original ecosystem, making 3.5 million tonnes of food annually available for seabirds and fish feeding on plankton, assuming that the biomass production did not change during the whaling period (Weslawski et al. unpubl. ms). Since little auks (Alle alle), polar cod (Boreogadus saida) and capelin (Mallotus villosus) feed on the same food as the Greenland right whale, they must have been the first organisms which benefited from its extermination. Increasing populations of polar cod and capelin have stimulated the increase of fish-eating birds, such as Brünnich's and common guillemots (Uria lomvia and Cepphus grylle) as well as Greenland seals (Phoca groenlandica) and minke whales (Balaenoptera acutorostrata) (Mehlum \& Gabrielsen 1993; Weslawski et al. unpubl. ms).

In relation to this, it is interesting to note that research in Antarctica has shown that three of the bird species which are abundant and almost totally dependent on Antarctic krill (Euphausia superba) - chinstrap (Pygoscelis antarctica), Adelie (Pygoscelis adeliae) and Macaroni (Eudyptes chrysolophus) penguins - have increased by 5 to $10 \%$ in number since after the modern whaling period (Croxall 1984; Laws 1985; Croxall et al. 1988). The same research clearly indicates that after the increase in the number of penguins, populations of the minke whale, crabeater seal (Lobodon carcinophagus) and even the Antarctic fur seal (Arctocephalus gazella) have grown too (Laws 1985).

If the same happened in the Arctic after the Greenland right whale population was decimated as a result of hunting, plankton-feeding birds such 
Table 1. Bird information from written sources: presence, catch possibility and taste.

\begin{tabular}{|c|c|c|c|c|c|}
\hline $\begin{array}{l}\text { Bird } \\
\text { Species }\end{array}$ & $\begin{array}{l}\text { Presence in } \\
\text { the wintering } \\
\text { logbook of } \\
1633-34^{1}\end{array}$ & $\begin{array}{l}\text { Recent } \\
\text { presence }\end{array}$ & $\begin{array}{l}\text { Catch } \\
\text { possibility }\end{array}$ & Taste & Quotation F. Martens, Voyage to Spitzbergen. $1671^{2}$ \\
\hline Kittiwake & +++ & +++ & ++ & 0 & $\begin{array}{l}\text { There is but little meat upon them. We eat but the } \\
\text { legs and the breast, for the wings are nothing but } \\
\text { skin and bone. }\end{array}$ \\
\hline Glaucous gull & + & + & ++ & 0 & \\
\hline $\begin{array}{l}\text { Brünnich's } \\
\text { guillemot }\end{array}$ & + & ++ & 0 & 0 & $\begin{array}{l}\text { The old ones are full of flesh, but it is very dry and } \\
\text { tough and therefore unpleasant to eat. } \\
\text { They boil them like the pigeons and scum off the } \\
\text { fat when they boil, then they fry them in batter. }\end{array}$ \\
\hline Black guillemot & +++ & + & 0 & + & $\begin{array}{l}\text { Their flesh is good to eat when the fat is taken away } \\
\text { from it, if afterwards it be fryed in butter. }\end{array}$ \\
\hline Little auk & 0 & +++ & ++ & ++ & $\begin{array}{l}\text { They are very good food, and the best next the } \\
\text { Strandrunner; are fleshy and fattish; we boyl and } \\
\text { then roast them. }\end{array}$ \\
\hline $\begin{array}{l}\text { Common } \\
\text { guillemot }\end{array}$ & 0 & + & 0 & 0 & \\
\hline Puffin & 0 & + & 0 & ++ & $\begin{array}{l}\text { He hath more flesh upon him than the diving pigeon } \\
\text { and is very good to eat. }\end{array}$ \\
\hline Fulmar & + & +++ & ++ & 0 & $\begin{array}{l}\text { His breast and legs are only to be eaten; they are } \\
\text { tough and taste strong of train oyl. }\end{array}$ \\
\hline Eider & +++ & $++t$ & + & + & $\begin{array}{l}\text { These ducks have a very good flesh. We boyl'd and } \\
\text { roasted them as we did the other birds, but the fat } \\
\text { of them we flung away for it tasted of train-oyl } \\
\text { (and made us vomit). }\end{array}$ \\
\hline \multicolumn{4}{|c|}{$\begin{array}{l}\text { '1' Honoré Naber (1930). } \\
\text { 'In White (1855). }\end{array}$} & \multicolumn{2}{|c|}{$\begin{array}{l}+++ \text { Very much/very good. } \\
++ \text { Much/good. } \\
+ \text { Fair. } \\
\text { 0 Poor. }\end{array}$} \\
\hline
\end{tabular}

as little auks and fish such as polar cod and capelin would have increased, followed by birds and sea mammals feeding on these fish. Recent observations have shown a high representation of little auk and kittiwake (Rissa tridactyla) on the west coast of Spitsbergen. Nowadays, these two species account for almost $65 \%$ of the total number of seabirds there (Norderhaug et al. 1977; Joiris 1996). Historical sources, however, tell another story. The birds mentioned in the wintering logbook of 1633-34 are kittiwake, fulmar (Fulmarus glacialis), Brünnich's guillemot, black guillemot (Cepphus grylle), glaucous gull (Larus hyperboreus) and eider (Somateria mollissima). Black guillemot, kittiwake and eider are mentioned most but there is no little auk in the logbook (Table 1) (1' Honoré Naber 1930).

The archaeological samples from the middens of the settlements near the rookeries contained bones from fulmar, kittiwake, glaucous gull, Brünnich's guillemot, black guillemot, little auk, eider and barnacle goose (Branta leucopsis) (van
Wijngaarden-Bakker \& Pals 1981; van Wijngaarden-Bakker 1984; Prummel 1998). In Smeerenburg (north-west Spitsbergen), fulmar bones were most frequently found in the samples $(79.7 \%)$, but this was probably because the flensing took place on the beach instead of alongside the ship. The whale carcasses attracted fulmars. Kittiwake and Brünnich's guillemot were also very well represented in the samples from Smeerenburg but almost no little auks (Table 2). However, not many fulmar bones were found in the middens of Laegerneset. In the samples from this place in Recherchefjorden near Bellsund (southern Spitsbergen) many bones from Brünnich's guillemots were found $(79.1 \%)$. The middens of Smeerenburg contained only a few bones of the little auk $(0.6 \%)$ and those of Laegerneset did not contain any bones of the little auk despite this bird being very well represented in present ornithological inventories (34.7\%) (Norderhaug et al. 1977; Joiris 1996). According to the written sources this bird was eaten by the whalers as much as all the others.

The hunting of the Greenland right whale in Svalbard 
Table 2. Number of bird bones from Smeerenburg (1979-1984) and Lægerneset (1998) compared with recent sea bird inventories (1991). Sources: van Wijngarden-Bakker (1984); Joiris (1996); Prummel (1998).

\begin{tabular}{lrrrrrr}
\hline Seabirds & \multicolumn{2}{c}{ SMB } & \multicolumn{2}{c}{ Lxgerneset } & \multicolumn{2}{c}{ Recent } \\
\hline Fulmar & 3290 & $79.7 \%$ & 43 & $5.4 \%$ & 383 & $10.3 \%$ \\
Kittiwake & 333 & $8.1 \%$ & 16 & $2 \%$ & 1151 & $31.0 \%$ \\
Glaucous gull & 114 & $2.8 \%$ & 25 & $3.1 \%$ & 138 & $3.7 \%$ \\
Brünnich's guillemot & 179 & $4.3 \%$ & 635 & $79.1 \%$ & 600 & $16.2 \%$ \\
Black guillemot & 51 & $1.2 \%$ & 9 & $1.1 \%$ & 65 & $1.8 \%$ \\
Little auk & 23 & $0.6 \%$ & & & 1289 & $34.7 \%$ \\
Common guillemot & & & & & 3 & $0.1 \%$ \\
Puffin & 136 & $3.3 \%$ & 75 & $9.3 \%$ & & $2.2 \%$ \\
Various & 4126 & $100 \%$ & 803 & $100 \%$ & 3711 & $100 \%$ \\
& & & & & & \\
\hline
\end{tabular}

They even liked this bird very much and it was easy to catch. So why are the bones of this bird almost not represented in the archaeological samples (Table 1)? The absence was most probably a question of scarcity. The knowledge that nowadays one third of all the birds of Svalbard are little auks means that as a result of the extermination of the Greenland right whale in the North Atlantic this bird has increased enormous in number during the last four centuries.

\section{Conclusions}

This study demonstrates that with the help of historical, archaeological, pedological and biological sources, it is possible to reconstruct the ecology of an animal that was exterminated more than 100 years ago in the North Atlantic. Using preserved catch records, it was possible to calculate the number of Greenland right whales before and during the first years of exploitation.

Catch records of the Greenland right whale show that whaling contributed greatly to the extermination of this whale species. However, climate records show that climate change contributed to this extermination. The impact of whaling on the population was particularly great when the pack ice was closed during cold periods and the whales could not escape from their hunters into the ice. This situation accelerated the elimination of the Greenland right whale from the Arctic ecosystem. This elimination has led to a surplus of zooplankton which is almost certainly consumed by fish and little auk, whose populations have increased enormously in number, with an alltime high cod population in the North Atlantic and little auk setting up new rookeries on the rocks of the west coast of Spitsbergen. This means that today's North Atlantic ecosystem has been strongly influenced by two centuries of human whaling. This ecosystem is not in equilibrium and the large quantities of cod and little auks of the last decades are not normal. Biologists need to understand climate and historical background of a region in order to make sound plans concerning management of ecosystems. Finally this study makes clear that multidisciplinary research is essential to understand the relationship between human actions, animal behaviour, climate change and environmental developments.

\section{References}

Bruijn, J. R. 1988: De walvisvaart: de ontplooiing van een nieuwe bedrijfstak. (Whaling: the development of a new branch of industry.) In L. Hacquebord \& W. H. Vroom (eds.): Walvisvaart in de gouden eeuw. Opgravingen op Spitsbergen. (Whaling in the Golden Age. Excavations on Spitsbergen.) Pp. 16-29. Amsterdam: De Bataafse Leeuw.

Burns, J. J., Montague, J. J. \& Cowles, C. J. (eds.) 1993: The bowhead whale. Special publication no. 2. Lawrence: Soc. for Marine Mammalogy.

Conway, M. 1900: Some unpublished Spitsbergen mss. Geogr. J. 15, 628-635.

Croxall, J. P. 1984: Seabirds. In R. M. Laws (ed.): Antarctic ecology. Pp. 533-616. London: Academic Press.

Croxall, J. P., McCann, T. S., Prince, P. A. \& Rothery, P. 1988: Reproductive performance of seabirds and seals at South Georgia and Signy Island, South Orkney Islands, 1976-1987. Implications for Southern Ocean Monitoring Studies. In D. Sahrhage (ed.): Antarctic Ocean and resources variability. Pp. 261-285. Berlin: Springer.

Dansgaard, W.. Clausen, H. B. \& Langway, C. C. 1970: Climatic oscillations 1200-2000 A.D. Nature 227, 482-483. 
de Korte, J. \& Belikov, S. E. 1994: Observations of Greenland whales (Balaena mysticetus), Zemlya Frantsa Iosifa. Polar Rec. 30, 135-136.

Everitt. R. D. \& Krogman, B. D. 1979: Sexual behavior of the bowhead whales observed off the north coast of Alaska. Arctic 32, 277-280.

Fisher, D. A. \& Koerner, R. M. 1980: Some aspects of climatic changes in the high Arctic during the Holocene as deduced from ice cores. In W. C. Mahaney (ed.): Quaternary paleoclimate. Pp. 249-271. Norwich (UK): Geo Abstracts.

Hacquebord, L. 1984a: Smeerenburg. Het verblijf van Nederlandse walvisvaarders op de westkust van Spitsbergen in de zeventiende eeuw. (Sineerenburg. The sojourn of Dutch whalers on the west coast of Spitsbergen in the seventeenth centurv.) $\mathrm{PhD}$ thesis, University of Amsterdam.

Hacquebord, L. 1984b: The history of early Dutch whaling: a study from the historical angle. 135-148. In H. K. s'Jacob et al. (eds.): Arctic whaling. Pp. 135-148. Groningen: University of Groningen.

Hacquebord, L. 1988a: Traankokerijen op de kusten van Spitsbergen; wat de historische archeologie ons ervan leert. (Whaling stations on the coast of Spitsbergen; what historical archaeology can teach us about them.) In L. Hacquebord \& W. H. Vroom (eds.): Walvisvaart in de gouden eeuw. Opgravingen op Spitsbergen. Pp. 49-65. Amsterdam: De Bataafse Leeuw.

Hacquebord, L. 1988b: 17th century whaling stations in southeastern Svalbard: an archaeological missing link. Polar Rec. 24, 125-128.

Hacquebord, L. \& Leinenga, J. R. 1994: De ecologie van de Groenlandse walvis in relatie tot walvisvaart en klimaatsveranderingen in de zeventiende en achttiende eeuw. (The ecology of the Greenland right whale in relation to whaling and climate change in the 17 th and 18th centuries). Tijdschr. voor Geschiedenis 107(3), 415-438.

Haldiman, J. T. \& Tarpley, R. J. 1993: Anatomy and physiology. In J. J. Burns et al. (eds.): The bowhead whale. Special publication no. 2. Pp. 71-156. Lawrence: Soc. for Marine Mammalogy.

Hazard, K. W. \& Lowry, L. F. 1984: Benthic prey in a bowhead whale from the northern Bering Sea. Arctic 37, 166-168.

IWC (International Whaling Commission) 1978: Reports of the Scientific Committee. Rep. Int. Whaling Comm. 28, 38-89.

Jackson, G. 1978: The British whaling trade. London: A. \& C. Black.

Joiris, C. R. 1996: At-sea distribution of seabirds and marine mammals around Svalbard, summer 1991. Polar Biol. 16, 423-429.

Kugler, R. C. 1984: Historical survey of foreign whaling: North America. In H. K. s'Jacob et al. (eds.): Arctic whaling. Pp. 149-157. Groningen: University of Groningen.

Laws, R. M. 1985: The ecology of the Southern Ocean. Am. Sci. $73,26-40$.

Leatherwood, S. \& Reeves, R. R. 1983: The Sierra Club handbook of whales and dolphins. San Francisco: Sierra Club.

1' Honoré Naber, S. P. 1930: Walvischvaarten, overwinteringen en jachtbedrijven in het hooge noorden 1633-1635. (Whaling voyages, winterings and hunting parties in the high north 1633-1635.) Utrecht: A. Oosthoek.
Mehlum, F. \& Gabrielsen, G. W. 1993: The diet of high-Arctic seabirds in coastal and ice-covered, pelagic areas near the Svalbard archipelago. Polar Res. 12, 1-20.

Mitchell, E. 1977 (unpubl.): Initial population size of bowhead whale (Balaena mysticetus) stocks: cumulative catch estimates. Cambridge (UK): Unpublished IWC report.

Mitchell. E. \& Reeves, R. R. 1981: Catch history and cumulative catch estimates of initial population size of cetaceans in the eastern Canadian Arctic. Rep. Int. Whaling Comm. 31, 645-682.

Moore. S. E. \& Reeves, R. R. 1993: Distribution and movement. In J. J. Burns et al. (eds.): The bowhead whale. Special publication no. 2. Pp. 313-386. Lawrence: Society for Marine Mammalogy.

Nerini, M. K., Braham, H. W., Marquette, W. M. \& Rugh, D. J. 1984: Life history of the bowhead whale, Balaena mysticetus (Mammalia: Cetacea). J. Zool. 204, 443-468.

Norderhaug, M., Brun, E. \& Ulenberg Møllen, G. 1977: Barentshavets sjofiglressurser. (Barents Sea seabird colonies.) Meddelelser 104. Oslo: Norwegian Polar Institute.

Overpeck, J. et al. 1997: Arctic environmental change of the last four centuries. Science 278, 1251-1257.

Prummel, W. 1998: Spitsbergen 1998, Laegerneset, animal remains from two sites. Internal report, Groningen Institute for Archaeology, University of Groningen.

Scoresby Jr., W. 1820: An account of the Arctic regions, with a history and description of the northern whale-fishery. Edinburgh: A. Constable \& Co.

Tarussov, A. 1992: The Arctic from Svalbard to Severnaya Zemlya: climatic reconstructions from ice cores. In $\mathrm{R}$. S. Bradley \& P. D. Jones, (eds.): Climate since A.D. 1500. Pp. 505-516. London: Routledge.

van der Knaap, W. O. 1985: Human influence on natural Arctic vegetation in the 17 th century and climate change since A.D. 1600 in northwest Spitsbergen: a paleobotanical study. Arct. Alp. Res. 17(4), 371-387.

van Wijngaarden-Bakker, L. H. 1984: De dierenresten van Smeerenburg; een poging tot reconstructie van de dierlijke component in de voeding van de $17 \mathrm{de}$ eeuwse walvisvaarders. (Animal remains from Smeerenburg; an attempt to reconstruct the animal part in the diet of the 17 th century whalers.) In L. Hacquebord: Smeerenburg. PhD thesis. University of Amsterdam.

van Wijngaarden-Bakker, L. H. \& Pals, J. P. 1981: Life and work in Smeerenburg. The bioarchaeological aspects. In A. F. G. van Holk et al. (eds.): Early European exploitation of the northern Atlantic 800-1700, 133-151. Groningen: University of Groningen.

Vinje, T. 1998: Barents Sea ice observations since 1596 and climate changes. Proceedings International Willem Barentsz Synposium 1997. Pp. 77-79. Harlingen: Flevodruk.

Weslawski, J. M., Hacquebord, L., Stempniewicz, L. \& Malinga, M. unpubl. ms: The place of the Greenland whale and walruses in the Svalbard coastal food web prior to and after exploitation.

White, A. (ed.) 1850: Documents on Spitzbergen and Greenland. Hakluyt Society. New York: Burt Franklin Publisher.

Woodby D. A. \& Botkin, D. B. 1993: Stock sizes prior to commercial whaling. In J. J. Burns et al. (eds.): The bowhead whale. Special publication no. 2. Pp. 387-407. Lawrence: Society for Marine Mammalogy. 